\title{
Assessment of Genetic Diversity and Relationships Among Caladium Cultivars and Species Using Molecular Markers
}

\author{
Zhanao Deng', Fahrettin Goktepe, and Brent K. Harbaugh \\ University of Florida/IFAS, Environmental Horticulture Department, Gulf Coast Research and \\ Education Center, 14625 CR 672, Wimauma, FL 33598 \\ Jinguo Hu \\ USDA-ARS, Northern Crop Science Laboratory, Fargo, ND 58105
}

\begin{abstract}
AdDitional INDEX words. Araceae, aroid, Caladium $\times$ hortulanum, C. bicolor, C. schomburgkii, germplasm, target region amplification polymorphism

Abstract. Caladium (Caladium $\times$ hortulanum Birdsey) is an important aroid widely used in the ornamental plant industry. Concerns have been raised about possible loss of genetic diversity due to a drastic decline in the number of cultivars in the last century. This study assessed genetic diversity and relationships among caladium cultivars and species accessions. Forty-five major cultivars and 14 species accessions were analyzed based on 297 DNA fragments produced by the target-region amplification polymorphism marker system. A low level of diversity $(44.4 \%$ polymorphism) was exhibited in cultivars, while a high level of diversity $(96.8 \%$ polymorphism) was present among seven accessions of Caladium bicolor (Aiton) Vent., Caladium marmoratum Mathieu, Caladium picturatum C. Koch, and Caladium schomburgkii Schott. A small percentage (7.6\%) of DNA fragments was present in cultivars but absent in the seven species accessions, while a high percentage (32.2\%) of DNA fragments was present in the seven species accessions but absent in cultivars. Cultivars shared a higher level of similarity at the molecular level with an average Jaccard coefficient at $\mathbf{0 . 8 0 2}$, formed a large group in cluster analysis, and concentrated in the scatter plot from a principal-coordinate analysis. Two accessions of $C$. bicolor and $C$. schomburgkii were very similar to cultivars with Jaccard similarity coefficients from 0.531 to 0.771 , while the rest of the species accessions had small similarity coefficients with cultivars (0.060 to 0.386). Caladium steudnirifolium Engler and Caladium lindenii (André) Madison were very dissimilar to $C$. bicolor, $C$. marmoratum, $C$. picturatum, and $C$. schomburgkii, with Jaccard similarity coefficients from 0.149 to $0.237(C$. steudnirifolium) and from 0.060 to 0.118 (C. lindenii). There is a limited amount of molecular diversity in caladium cultivars, but the great repertoire of unique genes in species accessions could be used to enhance the diversity in future cultivars and reduce potential genetic vulnerability.
\end{abstract}

Caladiums (Caladium Vent.) are members of the aroid family, widely grown as potted or bedding plants in the landscape. Commercial plants are generally forced from tubers. Over $95 \%$ of the tubers used worldwide are produced in Florida (Wilfret, 1993). Cultivar development in caladiums has a history of some 150 years (Hayward, 1950). At one time, there were more than 2000 named cultivars (Hayward, 1950). However, the number of caladium cultivars has been declining. For example, by 1970 only 141 cultivars were listed in Exotica (Graf, 1970). Recent surveys of Florida tuber producers in 1998 (Bell et al., 1998) and in 2003 (Deng et al., 2005c) indicated 90 and 92 cultivars in commercial production, respectively. Among them, 50 cultivars accounted for $>95 \%$ of the acreage used in tuber production (Bell et al., 1998; Deng et al., 2005c). As a result, there is increasing concern over the loss of genetic diversity in caladium via loss of cultivars. Similar concerns have been raised for other ornamental aroids (Chen et al.,

Received for publication 9 Aug. 2006. Accepted for publication 15 Dec. 2006. This project was supported by the Florida Agricultural Experiment Station.

We thank Dr. Harry E. Luther, Marie Selby Botanic Gardens, for giving us the access to the caladium species accessions, Richard O. Kelly and Joyce Jones for collecting leaf samples, Angelia Hogness for technical help with marker analysis, Chris Patte for his effort to score the gel images, and Drs. Gerald J. Seiler, Jake Henny, Jianjun Chen, and Brady A. Vick for critical reading of the manuscript.

${ }^{1}$ Corresponding author: E-mail: zdeng@ufl.edu. 2004a, 2004b, 2004c; Henny, 1977). Reduced genetic diversity could result in increased vulnerability to new diseases and pests and in reduced genetic variation for cultivar development. Some genetic vulnerability might have appeared in caladiums in the last 20 years. A viroid disease called "grassy tuber" emerged in the late 1980s (Polston et al., 1991), and a fungal disease, fusarium tuber rot [Fusarium solani (Mart.) Saa.], became severe (McGovern, 2004). Because of these diseases, a number of cultivars have been eliminated from commercial production (McGovern, 2004).

Preserving germplasm requires information on the level of genetic diversity and the relationships among cultivars. A previous study indicated a low level of diversity among seven caladium cultivars (Loh et al., 1999). Caladiums are neotropical plants, primarily propagated asexually, and prone to mutate in vitro (Chu and Yazawa, 2001). Maintaining many cultivars in vivo or in vitro will be costly. One option might be to maintain a core collection of cultivars for future breeding purposes. Knowing the genetic relationships among cultivars could help in deciding which ones to include in this core collection. This knowledge could be helpful for choosing parents for crosses because most cultivars presently grown do not have much pedigree information in the literature. In addition to cultivars, species accessions represent another important source of genetic variation. This source could be used to enhance the genetic diversity in caladium cultivars. Thus far, only two such 
Table 1. List of 45 caladium commercial cultivars (Caladium $\times$ hortulanum) used in this study, their leaf characteristics (shape, main vein color, impact color, and presence of spots or blotches), stress tolerance, pest and disease resistance, and breeders. 9

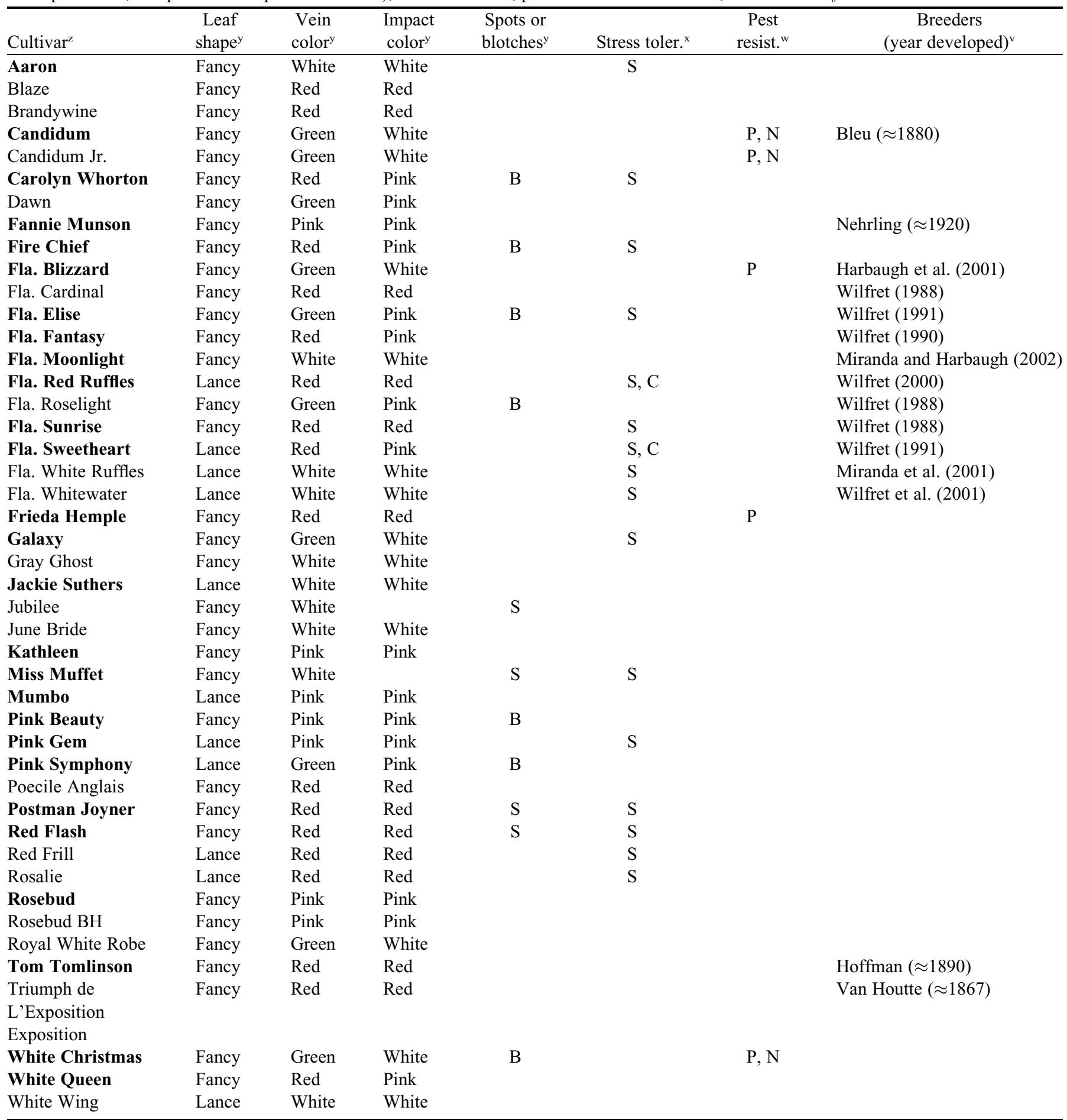

${ }^{\mathrm{z}}$ Fla. $=$ Florida. The 27 cultivars shown in bold type carried representative or low-frequency TRAP markers or possessed desirable leaf and tuber characteristics, stress tolerance, or pest or disease resistance and might be candidates for developing a core collection of caladium germplasm. ${ }^{\mathrm{y}}$ Categories of leaf shape, main vein color, impact color, and presence of spots or blotches based on Wilfret and Hurner (1982), Bell et al. (1998), and personal observations.

${ }^{x}$ Stress tolerance: $\mathrm{S}=$ sun tolerance, and $\mathrm{C}=$ cold tolerance. Sun tolerance based on Bates-Cantwell (2001) and growers and authors' personal observations; cold tolerance based on Deng and Harbaugh (2006).

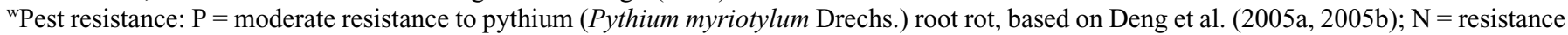
to root-knot nematode [Meloidogyne incognita (Kofoid and White) Chitwood], based on Dover et al. (2005) and McSorley et al. (2003).

`Inferred from Hayward (1950) or from recent release data from University of Florida's caladium breeding program. 
Table 2. List of Caladium species, Alocassia, and Colocasia accessions used in this study, their collection sites, collection identification numbers (ID), and code assigned. ${ }^{z}$

\begin{tabular}{|c|c|c|c|}
\hline Accession code & Classification $^{z}$ & $\begin{array}{c}\text { Collection } \\
\text { site }^{z}\end{array}$ & Collection $\mathrm{ID}^{\mathrm{z}}$ \\
\hline$\overline{\mathrm{Bi} 7 \mathrm{~B}}$ & C. bicolor & - & $\begin{array}{l}1997-0277 B \\
\end{array}$ \\
\hline $\mathrm{Bi} 3 \mathrm{~A}$ & C. bicolor & - & 1983-0353A \\
\hline $\mathrm{Bi3B}$ & C. bicolor & Ecuador & 1983-0353B \\
\hline $\mathrm{Hm} 9 \mathrm{~B}$ & C. humboldtii & $\begin{array}{l}\text { South } \\
\text { America }\end{array}$ & 1977-1979B \\
\hline $\mathrm{Hm} 9 \mathrm{C}$ & C. humboldtii & $\begin{array}{l}\text { South } \\
\text { America }\end{array}$ & 1977-1979C \\
\hline $\mathrm{HmM}$ & $\begin{array}{l}\text { C. humboldtii } \\
\text { Marcel }\end{array}$ & - & Fisk $996-1$ \\
\hline Li6A & C. lindenii & Colombia & 1986-0736A \\
\hline LiM & $\begin{array}{l}\text { C. lindenii } \\
\text { Magnificum }\end{array}$ & - & $1980-1202 \mathrm{~A}$ \\
\hline Mrm & C. marmoratum & - & $2000-0005 \mathrm{~A}$ \\
\hline $\mathrm{Pi} 2 \mathrm{~A}$ & C. picturatum & - & $1992-0422 \mathrm{~A}$ \\
\hline Pi9A & C. picturatum & Ecuador & 2001-0129A \\
\hline Shm & C. schomburgkii & Trinidad & $2000-0040 \mathrm{~A}$ \\
\hline $\mathrm{St} 2 \mathrm{~A}$ & C. steudnirifolium & Costa Rica & 1986-10002A \\
\hline St0A & C. steudnirifolium & Ecuador & 1989-0570A \\
\hline Alo4B & Alocasia cuprea & Malaysia & 1981-0794B \\
\hline Alo8A & Alocasia sinuata & Malaysia & 1995-0258A \\
\hline Col & Colocasia esculenta & - & $2002-0055 \mathrm{~A}$ \\
\hline
\end{tabular}

${ }^{\mathrm{z}}$ Plant materials or information kindly provided by H.E. Luther, Marie Selby Botanical Gardens, Sarasota, Fla.

"_." indicates data not available.

studies were conducted in caladium, and they were limited to four species and seven cultivars (Loh et al., 1999, 2000).

Genetic relationships and diversity among cultivars or species have been studied in a number of important ornamental aroids, including aglaonema (Aglaonema Schott) (Chen et al., 2004b), alocasia [Alocasia (Schott) G. Don] (Chen et al., 2004a), dieffenbachia (Dieffenbachia Schott) (Chen et al., 2004c), philodendron (Philodendron Schott) (Devanand et al., 2004), and syngonium (Syngonium Schott) (Chen et al., 2006). These studies have established the genetic similarity among cultivars and demonstrated the usefulness in assisting such studies for germplasm identification, preservation, and new cultivar development (Chen et al., 2004a, 2004b, 2004c; Devanand et al., 2004). In addition, they have revealed some interesting phenomena in aroids. For example, many dieffenbachia cultivars were less similar than was previously thought (Chen et al., 2004c). Most sports or variants had accumulated numerous somatic mutations through tissue culture (Chen et al., 2004c) and had Jaccard similarity coefficients below 0.73 . Similar work has been reported in other ornamental plants and confirmed the value of molecular marker analysis in assessing genetic diversity or understanding genetic relationships among cultivars and species (Ahmad et al., 2006; Carr et al., 2003; Han et al., 2000; Meerow et al., 2005; Parks and Moyer, 2004; Tomkins et al., 2001).

A number of PCR-based molecular marker systems have been used in analysis of genetic diversity and relationships of ornamental plants (Ahmad et al., 2006a; Carr et al., 2003; Chen et al., 2004a, 2004b, 2004c; Loh et al., 1999, 2000; Meerow et al., 2005). The target-region amplification polymorphism (TRAP) system is a recent addition to these PCR-based systems (Hu, 2006; Hu and Vick, 2003). It does not involve restriction digestion and adaptor linking, thus it should be easier and less expensive to run than amplified fragment-length polymorphism (AFLP), yet it can produce similar fingerprinting profiles and efficiency. This TRAP system has been used in assessing genetic diversity in sugarcane (Saccharum L.) germplasm collections (Alwala et al., 2006b) and estimating genetic similarities among genotypes often used as breeding parents (Alwala et al., 2006a), lettuce (Lactuca sativa L.) cultivar genotyping (Hu et al., 2005), genetic mapping of a male sterility gene of sunflower (Helianthus annuus L.) (Chen et al., 2006), and disease-resistance quantitative trait loci (QTLs) in bread wheat (Triticum aestivum L.) (Liu et al., 2005) and common bean (Phaseolus vulgaris L.) (Miklas et al., 2006). It has also been used to categorize the pelargonium (Pelargonium L'Hér.) collection maintained at the Ornamental Plant Germplasm Center in Columbus, Ohio (Palumbo et al., 2005). The objectives of this study were to assess the genetic diversity of major caladium cultivars and species accessions using the TRAP marker system.

\section{Materials and Methods}

Plant materials. Forty-five caladium cultivars and 14 species accessions were used in the present study (Tables 1 and 2). All cultivars were asexually propagated by tuber division and maintained at the University of Florida Gulf Coast Research and Education Center in Bradenton. The 14 species accessions were kindly provided by the Marie Selby Botanic Gardens in Sarasota, Fla. Two alocasia [Alocasia cuprea (K. Koch \& C.D. Bouche) K. Koch and Alocasia sinuata N.E. Br.] and one colocasia [Colocasia esculenta (L.) Schott] accessions were included as outgroups for the dendrogram.

Table 3. List of PCR primers used for target region amplification polymorphism (TRAP) marker development, their sequences, nature, and contig identification numbers (IDs) in the Compositae Genome Project database (Compositae Genome Project, n.d.).

\begin{tabular}{llll}
\hline Primer name & \multicolumn{1}{c}{ Sequence $\left(5^{\prime} \rightarrow 3^{\prime}\right)$} & Nature & Contig ID or reference \\
\hline A20I01a & CCGAGTTGGTATGCTTGT & Fixed & QHA20I01.yg.ab1 \\
B14G14b & AATCTCAAGGACAAAAGG & Fixed & QHB14G14.yg.ab1 \\
Ga3-800 & TCATCTCAAACCATCTACAC & Arbitrary & Li and Quiros (2001) \\
Ga5-800 & GGAACCAAACACATGAAGA & Arbitrary & Li and Quiros (2001) \\
QGB9J18L & TGGACTTCAACCAAGACA & Fixed & QGB9J18.yg.ab1 \\
QHF6H21L & ACAGGAAAAGCCTGTCAC & Fixed & QHF6H21.yg.ab1 \\
Sa4-700 & TTACCTTGGTCATACAACATT & Arbitrary & Li and Quiros (2001) \\
Sa12-700 & TTCTAGGTAATCCAACAACA & Arbitrary & Li and Quiros (2001) \\
\hline
\end{tabular}




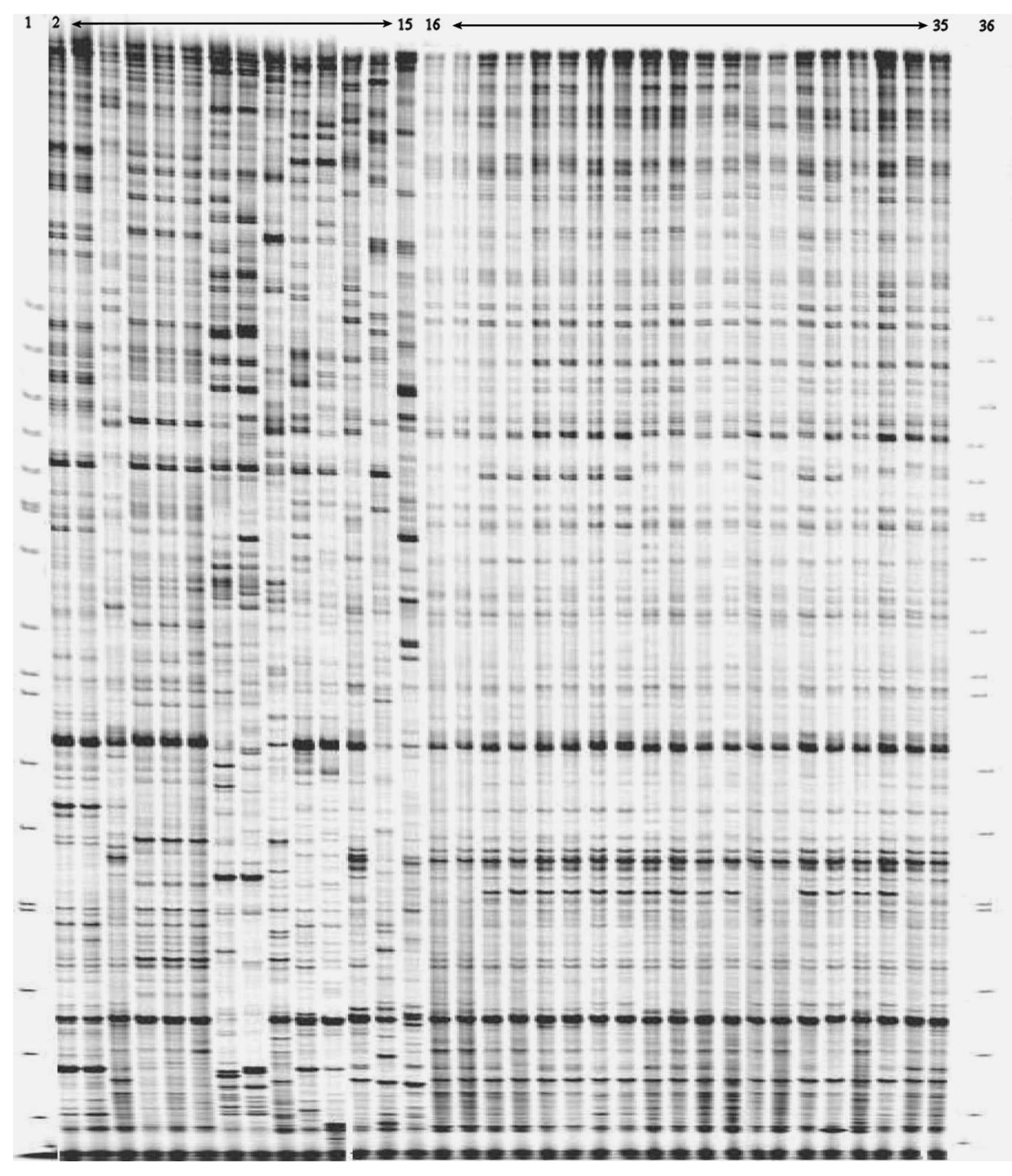

Fig. 1. Target region amplification polymorphism (TRAP) marker profile of 14 caladium species accessions (lanes 2-15 from left to right) and 20 cultivars (lanes 16-35) produced with primer combination PP1. Size markers are in lanes 1 and 36.

For each cultivar or species accession, three newly emerged leaves free of diseases or insect damage were collected from mature plants in the spring of 2003. Leaves were washed and blotted dry in the laboratory; $\approx 200 \mathrm{mg}$ (fresh weight) of tissue was cut from the leaves and placed into 2-mL plastic collection tubes (Qiagen, Valencia, Calif.). Total genomic DNA was isolated from leaf tissue using the DNeasy Plant kit following the manufacturer's instructions (Qiagen). Concentrations of DNA in the preparations were determined using a DU7400 spectrophotometer (Beckman Coulter, Fullerton, Calif.) and adjusted to 10-20 ng $\mu \mathrm{L}^{-1}$ for PCR amplification.

TRAP MARKER ANALYSIS. Eight primers (Table 3) were used in PCR amplification and marker development. Four of the primers were called "fixed" primers, and the other four were called "arbitrary" primers. Fixed primers were designed against the annotated expressed sequence tag (EST) of sunflower (name starts with "QH") or lettuce (name starts with "QG") in the public Compositae Genome Project database (Compositae Genome Project, n.d.). Arbitrary primers were labeled at the $3^{\prime}$ end with an IR dye, IRD700 or IRD800, for detection of the presence and size of amplified DNA fragments. All primers were synthesized by LI-COR Biosciences (Lincoln, Nebr.) or MWG Biotech (Highpoint, N.C.).

Each of the PCR reactions was made to a final volume of $15 \mu \mathrm{L}$ containing $1 \times$ PCR reaction buffer (Qiagen), 20-40 ng of genomic DNA, $2.5 \mathrm{~mm} \mathrm{MgCl}_{2}, 0.33 \mathrm{~mm}$ dNTPs, 3 pmol each of IRD-700 and IRD-800 labeled arbitrary primers, 100 pmol of one of the fixed primers, and 1.5 units of Taq DNA polymerase (Qiagen). PCR amplification was performed on a GenAmp 9700 thermal cycler (Applied Biosystems, Foster City, Calif.) with the following parameters: $2 \mathrm{~min}$ at $94{ }^{\circ} \mathrm{C}$ for initial denaturation, 5 cycles of amplification at $94{ }^{\circ} \mathrm{C}$ for $45 \mathrm{~s}, 35^{\circ} \mathrm{C}$ for $45 \mathrm{~s}$, and $72{ }^{\circ} \mathrm{C}$ for 1 min, 35 cycles at $94{ }^{\circ} \mathrm{C}$ for $45 \mathrm{~s}$, $50{ }^{\circ} \mathrm{C}$ for $45 \mathrm{~s}$, and $72{ }^{\circ} \mathrm{C}$ for $1 \mathrm{~min}$, and a final extension step at $72{ }^{\circ} \mathrm{C}$ for $7 \mathrm{~min}$. Out of the 16 possible primer combinations that could be formed from the four fixed and the four arbitrary primers, eight primer combinations (PP1 to PP8) generated $>250$ markers and were used in this study.

PCR products were separated on a $6.5 \%$ polyacrylamide sequencing gel in $0.5 \times$ TBE buffer using a NEN Global DNA Sequencer (LI-COR, Lincoln, Nebr.). The gel was prerun for $10-20 \mathrm{~min}$ at $1500 \mathrm{~V}, 40 \mathrm{~mA}$, and $40 \mathrm{~W}$ to warm the gel to $45^{\circ} \mathrm{C}$. The PCR product was mixed with $7 \mu \mathrm{L}$ of $5 \times$ loading dye containing 0.313 м Tris- $\mathrm{HCl}\left(\mathrm{pH} 6.8\right.$ at $\left.25^{\circ} \mathrm{C}\right)$, $10 \%$ SDS, $0.05 \%$ bromophenol blue, and $50 \%$ glycerol. A $1-\mu \mathrm{L}$ aliquot of the reaction mixture was loaded to each well of the warm gel. Electrophoresis was then performed at $1500 \mathrm{~V}$ and $40 \mathrm{~mA}$ for $3.5 \mathrm{~h}$. DNA fragments (bands) were automatically detected by the DNA sequencer scanning the presence and intensity of IR signals from labeled arbitrary primers, and a gel image (Fig. 1) was generated by SAGA software (LI-COR).

Data ANALYSIs. DNA bands shown on the gel images were visually scored as present (1) or absent (0) for each cultivar/ species accession and each primer combination, which resulted in a binary dataset consisting of 0 and 1 . For each primer combination, the total numbers of clearly scorable DNA bands and the number of DNA bands polymorphic between cultivars or species accessions were recorded to calculate the percentage of polymorphic DNA bands. In addition, the polymorphism information content (PIC) value was calculated for each primer combination to provide an estimate of its discriminatory power (Vuylsteke et al., 2000). The PIC value for each marker locus was equal to 
Table 4. Total number of DNA bands scored, number and percentage of polymorphic bands, and polymorphism information content (PIC) value for each of the eight primer combinations (PP1 to PP8) in 45 caladium cultivars, seven selected species accessions (C. bicolor, C. marmoratum, C. picturatum, and C. schomburgkii), and all 59 caladiums (45 cultivars and 14 species accessions) included in this study.

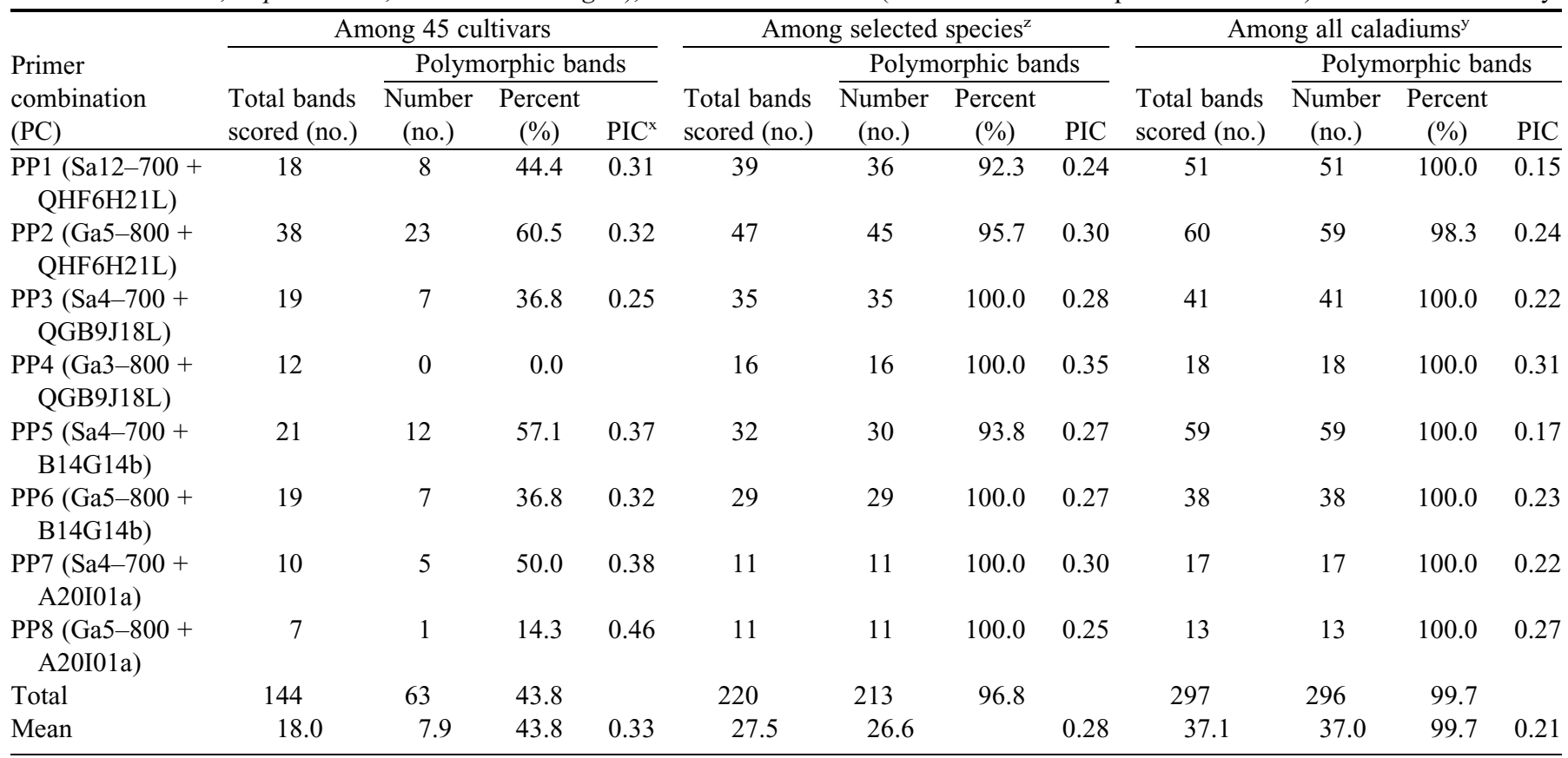

${ }^{\mathrm{Z}}$ Including seven accessions of C. bicolor, C. marmoratum, C. picturatum, and C. schomburgkii, which might have contributed to the development of caladium cultivars (Bell et al., 1998; Hayward, 1950; Wilfret, 1993).

${ }^{\mathrm{y}}$ Including all 45 cultivars and 14 species accessions used in the study.

xolymorphism information content.

$$
1-\sum_{i=1}^{n} f i^{2}
$$

where $f_{i}$ is the frequency of the $i$ th allele at a marker locus. Because TRAP markers were scored as dominant markers, only two states (presence and absence) could be distinguished at each band position, and the value of $n$ was equal to 2 . The highest PIC for a dominant marker would be 0.5 (Vuylsteke et al., 2000). The PIC value for each primer combination was calculated as

$$
\sum_{j=1}^{N} \mathrm{PIC}_{j} / N
$$

where $\mathrm{PIC}_{j}$ is the PIC value of the $j$ th marker and $N$ is the number of polymorphic markers generated by a primer combination. Loci that were non-polymorphic among the cultivars or species accessions to be examined were excluded because their PIC values would be equal to 0 (Vuylsteke et al., 2000). The binary dataset was then used in the software package NTSYSPC, version 2.2 (Rohlf, 2005), to calculate the Jaccard coefficient of similarity (Sneath and Sokal, 1973) and to perform cluster analysis and principal-coordinate analysis. The formula for similarity coefficient calculation was Jaccard = $N_{\mathrm{AB}} /\left(N_{\mathrm{AB}}+N_{\mathrm{A}}+N_{\mathrm{B}}\right)$, where $N_{\mathrm{AB}}$ is the number of marker bands shared by two samples (A and $\mathrm{B}$ ), and $N_{\mathrm{A}}$ and $N_{\mathrm{B}}$ are the marker bands present only in sample A or B. Cluster analysis was conducted using the unweighted pair group method of the arithmetic averages (UPGMA), and its output was used to construct a dendrogram of caladium cultivars and species accessions. The goodness-of-fit of the dendrogram to the similarity matrix was tested in NTSYSpc by a cophenetic correlation analysis. To assess the dendrogram's branch support, bootstrap analysis was performed using the computer software FreETREE (Pavlicek et al., 1999) with 1000 runs of data resampling. Dendrograms produced by FreeTree with bootstrap values were displayed in TREEVIEW (Page, 1996). Principal-coordinate analysis (PCoA) was performed to show distribution of these cultivars and species accessions in a twoor three-dimensional scatter plot.

\section{Results and Discussion}

TRAP MARKERS IN CALADIUM. Eight primer combinations generated 297 clear-cut DNA bands in the 59 caladium samples. The number of DNA fragments amplified by each primer combination varied from 13 (PP8) to 60 (PP2), with an average of 37 fragments per primer combination (Table 4). Duplicate samples for three cultivars ('Blaze', 'Brandywine', and 'Dawn') shared $97.2 \%$ of the DNA fragments, indicating good reproducibility and reliability of the TRAP marker system in fingerprinting caladium samples (data not shown). PIC values, indicators of a marker system's discriminatory ability, varied among primer combinations and when different groups of caladium samples were considered (Table 4). When 45 caladium cultivars were considered, the PIC value for each primer combination ranged from 0.25 (PP3) to 0.46 (PP8), with an average of 0.33 . When all caladium cultivars and 14 species accessions were examined, the PIC value varied from 0.15 (PP1) to 0.31 (PP4), with an average of 0.21. This level of PIC in caladium seems to be comparable to the PIC of TRAP markers (based on different primer combinations) in sugarcane (Alwala et al., 2006b), in which the PIC value for 18 TRAP 


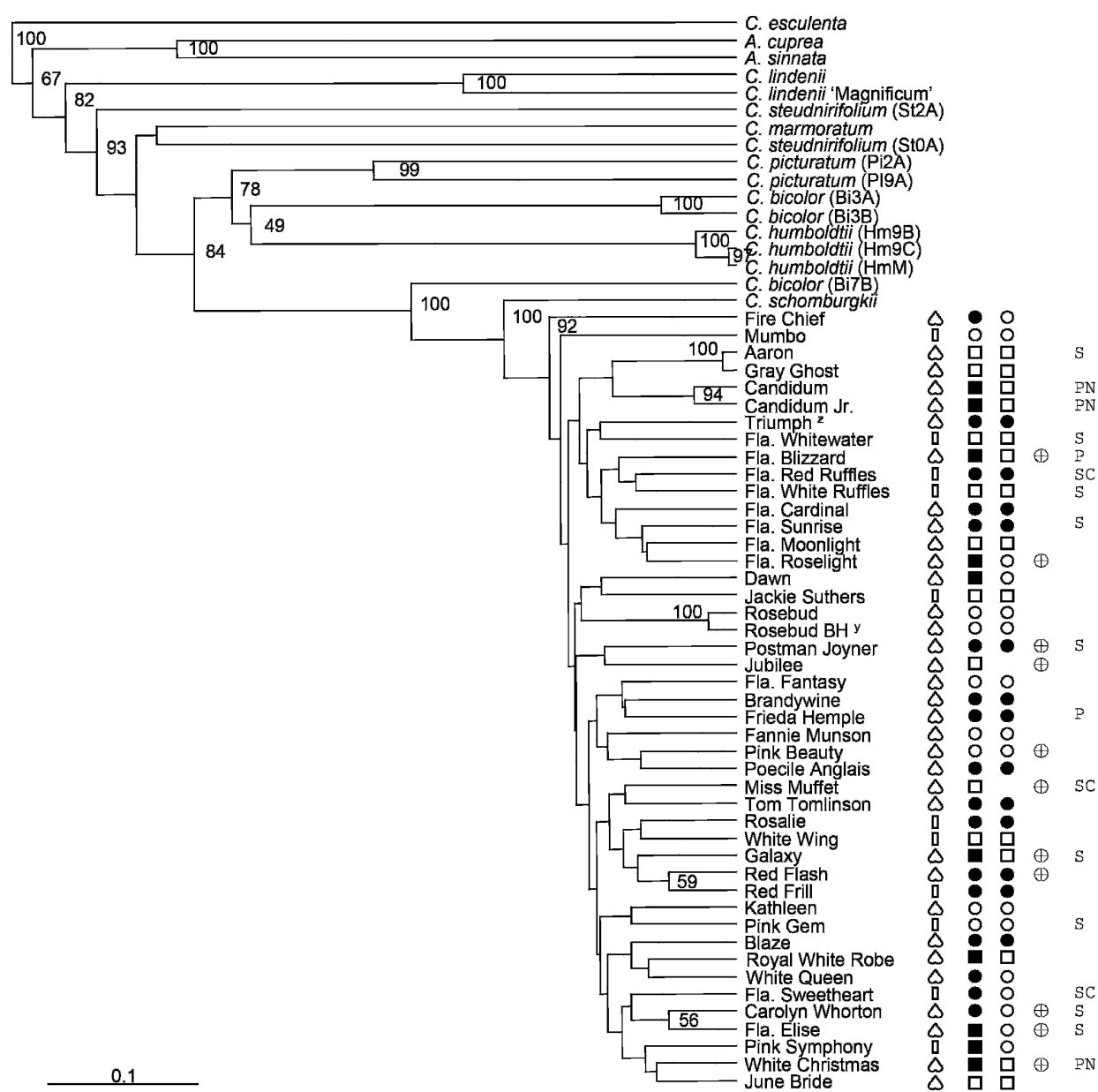

Fig. 2. Dendrogram of 45 caladium cultivars and 14 species accessions from UPGMA cluster analysis of Jaccard similarity coefficients estimated from 297 polymorphic DNA bands. Numbers next to the branches are bootstrap values (\%) out of 1000 data resampling runs. Bootstrap values are not shown for branches with values $<50 \%$. Cultivar names may be abbreviated: Triumph = 'Triumph de L' Exposition', Fla. = Florida, Rosebud $\mathrm{BH}=$ 'Rosebud Bear Hollow'. Symbols to the right of the cultivar names in the first, second, third, fourth, and fifth columns indicate leaf shape (heart = fancy, and short bar = lance), main vein color and impact color (solid square, open square, solid circle, and open circle = green, white, red, and pink, respectively), presence of spots or blotches $(\oplus)$, and stress tolerance, and/or pest resistance $(S=$ sun tolerance, $C=$ cold tolerance, $\mathrm{P}=$ moderate resistance to pythium root rot, $\mathrm{N}=$ resistance to root-knot nematodes).

primer combinations ranged from 0.11 to 0.36 with an average of 0.24. TRAP marker PIC values in caladium and sugarcane seem to be comparable to the PIC of AFLP markers in plantains (Musa L. subgroup AAB) [PIC =0.24 (Ude et al., 2003)], maize (Zea mays L.) [PIC $=0.22$ to 0.38 (Vuylsteke et al., 2000)], and wheat $[\mathrm{PIC}=0.32$ (Bohn et al., 1999)]. The number of DNA fragments amplified by each TRAP primer combination in caladium seems to be similar to that observed in sugarcane [15-58 scorable bands per primer combination (Alwala et al., 2006b)], sunflower [30-60 bands per primer combination (Chen et al., 2006)], and wheat [11-39 bands per primer combination (Liu et al., 2005)]. Hu (2006) suggested that the complex amplification profile of TRAP was likely to result from the low annealing temperature used during the initial several cycles of PCR amplification, which allows TRAP primers to anneal to both perfectly and imperfectly matched target sites in the plant genome. Cloning and sequencing TRAP fragments amplified in lettuce has confirmed that the majority of TRAP fragments indeed resulted from imperfect matches between the primers and the genomic sites (Hu et al., 2005).
GENETIC DIVERSITY AND RELATIONSHIPS AMONG CULTIVARS. Of the 297 DNA fragments amplified, 144 were present in caladium cultivars, and $63(44.4 \%)$ were polymorphic among cultivars (Table 4). The majority $(95.2 \%)$ of the polymorphic fragments were present in $10 \%$ to $90 \%$ (5-41) of the cultivars, while eight fragments were found in only $<10 \%(1-4)$ cultivars. Gel images were rechecked to confirm the presence and signal strength of these fragments. These lowfrequency (or unique) fragments appeared in six red-leaved cultivars (Blaze, Frieda Hemple, Fla. Cardinal, Poecile Anglais, Tom Tomlinson, Triumph de L'Exposition), five pink-leaved cultivars (Fannie Munson, Fire Chief, Fla. Fantasy, Mumbo, Pink Beauty), and four white-leaved cultivars (Aaron, Fla. Whitewater, Gray Ghost, Royal White Robe). 'Blaze' and 'Frieda Hemple' each carried two of the low-frequency fragments, while other 13 cultivars each carried one of these low-frequency fragments. Sixteen DNA fragments were present only in cultivars but absent in the seven accessions of $C$. bicolor, C. marmoratum, C. picturatum, and C. schomburgkii. When compared with the 14 species accessions, seven fragments present in cultivars were absent in the species accessions. This indicates that some unique DNA fragments or mutations might have occurred in the cultivars.

Jaccard similarity coefficients between cultivars ranged from 0.691 (between 'Fire Chief' and 'Triump de L'Exposition') to 0.982 (between 'Aaron' and 'Gray Ghost'), with an average of 0.799. 'Aaron' and 'Gray Ghost' had been suspected of being related cultivars and had the highest similarity coefficient (0.982) with a difference of only two markers. 'Rosebud Bear Hollow' was a grower's selection from 'Rosebud.' Morphologically, 'Rosebud' and 'Rosebud Bear Hollow' are indistinguishable. Their similarity coefficient was 0.963. 'Candidum Jr.' was believed to be a sport selection of 'Candidum' (Wilfret, 1991). 'Candidum' was reportedly developed by Bleu (a French pioneer of caladium hybridization) in $\approx 1880$ (Hayward, 1950). The two cultivars had a similarity coefficient of 0.945 with a difference of six markers. Excluding these six highly similar cultivars, the minimum, the maximum, and the average similarity coefficients between cultivars were $0.691,0.911$, and 0.802 , respectively.

All cultivars formed a large cluster in the dendrogram constructed from the Jaccard similarity coefficients of caladium cultivars and species accessions using the UPGMA method (Fig. 2). The cophenetic correlation between the dendrogram 


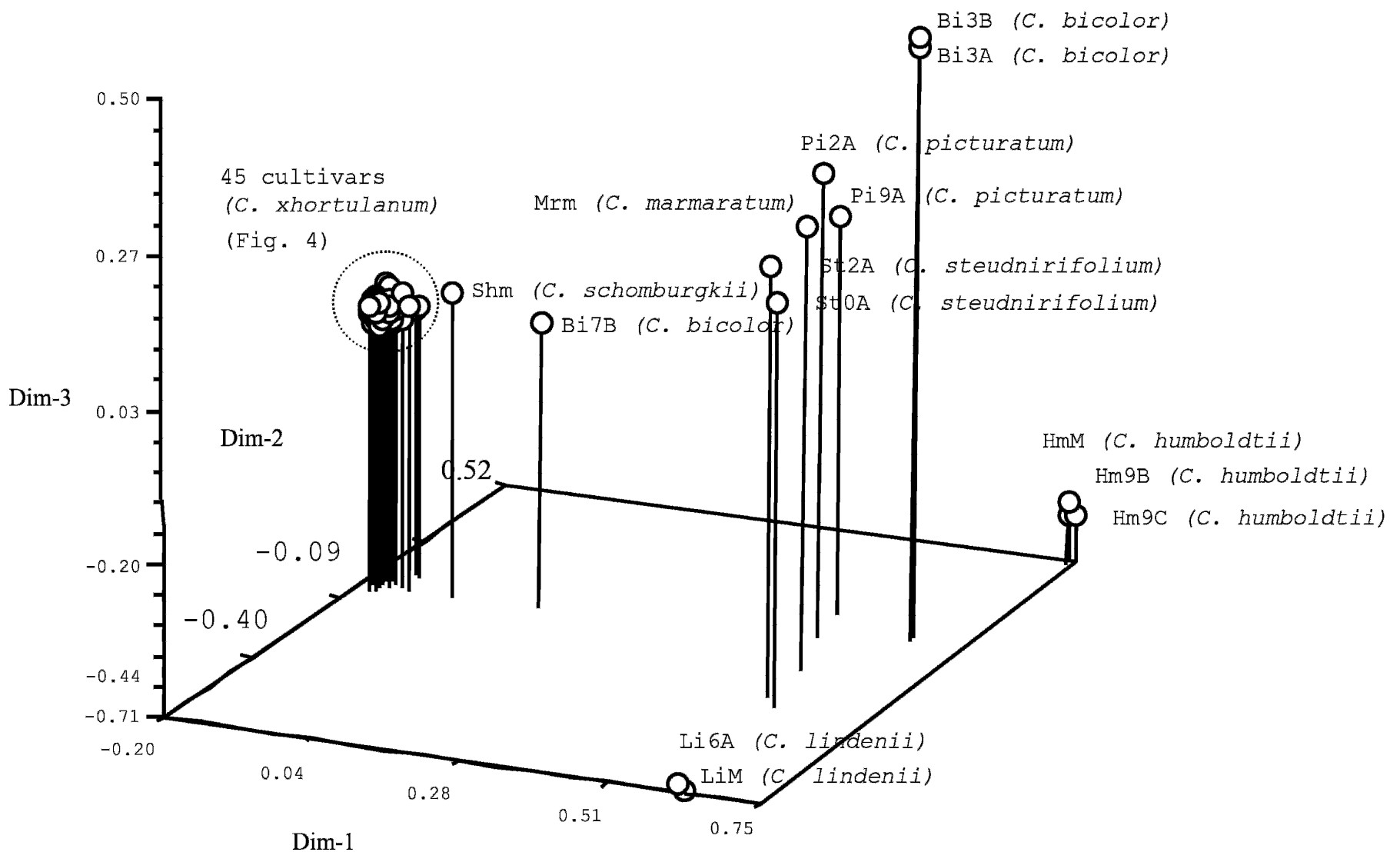

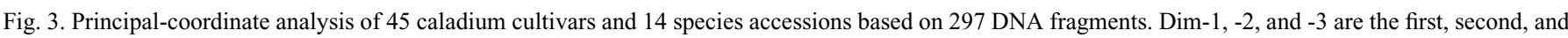
third axes, respectively, explaining $25.9 \%, 8.5 \%$, and $6.3 \%$ of the total variation. The 45 cultivars are concentrated in this plot but were separated when analysis was performed on the cultivars only, as shown in Fig. 4.

and the similarity matrix was strong $(0.995)$, indicating a very good fit of the dendrogram to the matrix. However, although the majority (11/15) of the clustering branches among species accessions were well supported with high bootstrap values ( $78 \%$ to $100 \%$ out of 1000 repetitions), only a few subclusters among cultivars had such high bootstrap values (Fig. 2). In addition, all cultivars were concentrated in the scatter plot according to the PCoA of all caladium cultivars and species accessions (Fig. 3). The first three axes resulting from the principal-coordinate analysis accounted $25.9 \%, 8.5 \%$, and $6.3 \%$ of the total variation, respectively, and cumulatively explained $40.7 \%$ of the total variation. The first axis clearly separated caladium cultivars from species accessions, and the second and the third axes separated species accessions. However, these axes were not able to separate caladium cultivars. A separate PCoA was performed on caladium cultivars only. The first and second axes accounted for $10.3 \%$ and $9.0 \%$ of the total variation, respectively, and separated all cultivars except 'June Bride' and 'Jubilee' (Fig. 4). No specific grouping was observed in the PCoA plot of the 45 cultivars.

Caladium cultivars are often grouped by leaf shape (fancy, lance, or strap) and impact color (white, red, pink, or multicolored) (Bell et al., 1998; Wilfret and Hurner, 1982). Of the 10 lance-leaved cultivars included in the analysis, 'Rosalie' and 'White Wing' clustered together, as did 'Florida Red Ruffles' and 'Florida White Ruffles.' But the rest ('Red Frill', 'Pink Gem', 'Pink Symphony', 'Whitewater', 'Florida Sweetheart', and 'Jackie Suthers') clustered with fancy-leaved cultivars
(Fig. 2). This appears to be unexpected at first glance, but it may be reasonable. Caladium leaf shape is controlled primarily by a single locus with two codominant alleles (Deng and Harbaugh, 2006; Wilfret, 1986). Therefore, the genetic component controlling leaf shape is rather minor compared with the 144 markers analyzed here or the whole caladium genome. Leaf shape has been used in separating caladium species such as C. schomburgkii. Caution may have to be used considering the simple genetic control involved.

GENETIC DIVERSITY AND RELATIONSHIP AMONG CALADIUM SPECIES. Out of the 297 DNA fragments scored in the 14 species accessions, one fragment was shared by all accessions, and 296 fragments were polymorphic among the accessions. This indicates $99.7 \%$ polymorphism in the species accessions (Table 4 ).

Previous literature indicated that several species, including C. bicolor, C. picturatum, C. marmoratum, or C. schomburgkii, might have contributed to the development of caladium cultivars (Bell et al., 1998; Hayward, 1950; Wilfret, 1993). The polymorphism (diversity) among these species accessions was compared with that in caladium cultivars. Out of 211 DNA fragments identified in one or more of these seven species accession or 45 cultivars, $127(60.1 \%)$ were present both in species and cultivars. However, 68 (32.2\%) fragments were present only in the seven species accessions but absent in cultivars. As mentioned above, the number of DNA fragments present in cultivars but absent in these species was $16(7.6 \%)$. This may indicate a great repertoire of genes in these species that have the potential to be introduced into caladium cultivars. 


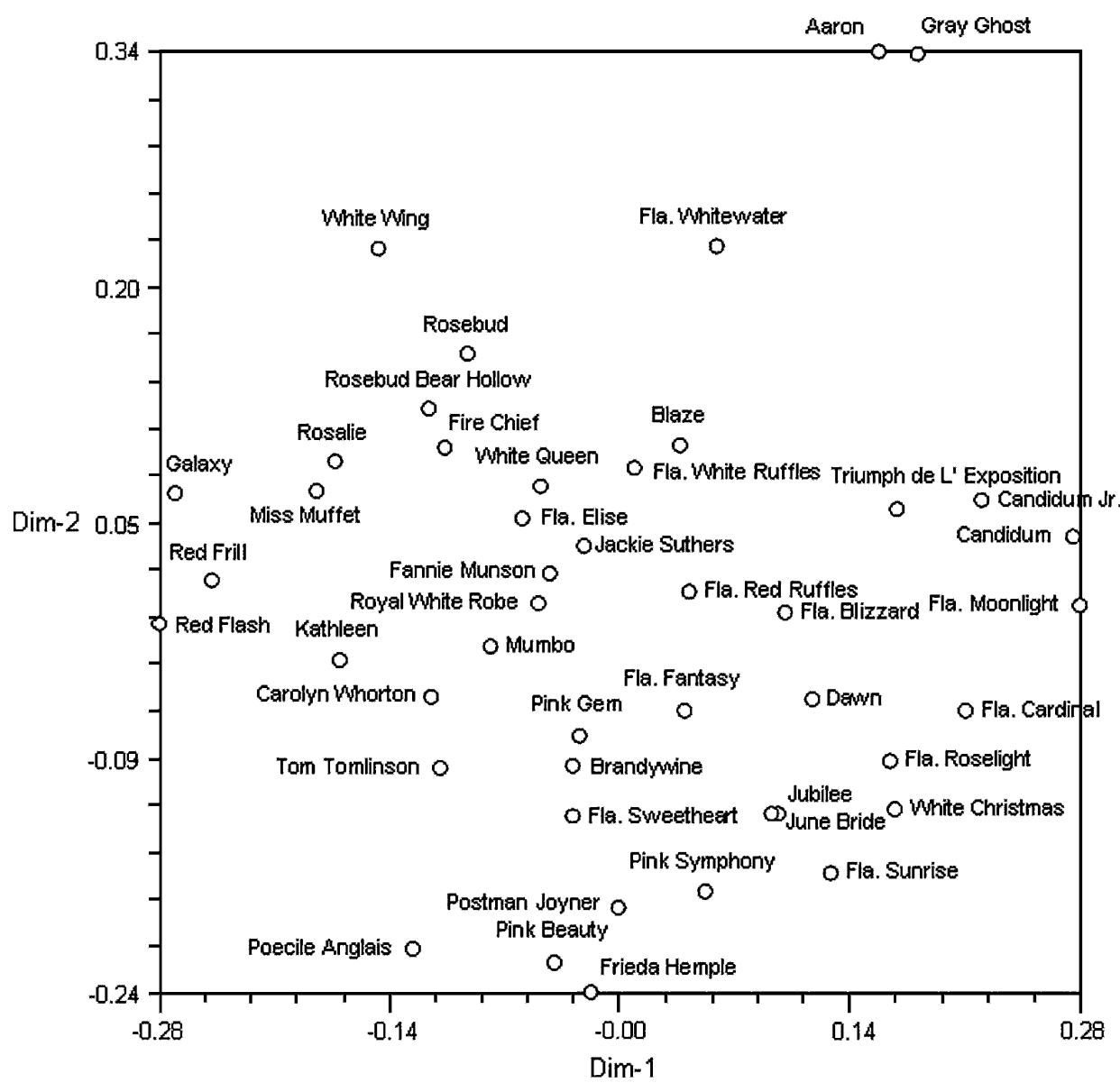

Fig. 4. Principal-coordinate analysis of 45 caladium cultivars based on 144 DNA fragments. The first two axes (Dim-1 and -2) cumulatively explain $19.3 \%$ of the total variation $($ Fla. $=$ Florida $)$.
Two $C$. picturatum accessions had the highest Jaccard similarity coefficients with $C$. humboldtii (0.308-0.416) and C. schomburgkii (0.342-0.376), followed by $C$. bicolor (0.263-0.383), C. marmoratum (0.233-0.275), C. steudnirifolium (0.155-0.184), and cultivars (0.124-0.211) (Table 5). The accessions had the lowest similarity with C. lindenii (0.071-0.094) (Table 5).

The two $C$. steudnirifolium accessions were quite divergent: their similarity coefficient was only 0.221 (Table 5). The accessions were collected from Ecuador and Costa Rica, respectively (H.E. Luther, Marie Selby Botanic Gardens, Sarasota, Fla.). This geographic separation might have allowed them to evolve independently. As a whole, the species was highly dissimilar to other species or cultivars, with similarity coefficients being between 0.131 and 0.237 with $C$. bicolor, C. humboldtii, C. marmoratum, C. picturatum, C. schomburgkii, and cultivars and 0.063-0.084 with C. lindenii.

C. humboldtii is unique compared with other caladium species. Plants are dwarf and miniature, and leaves display a unique coloration pattern. In addition, flowers have not been observed in cultivation.
The similarity of cultivars to species accessions varies remarkably (Table 5). The Jaccard coefficient with $C$. lindenii accessions was $0.105-0.148$, with $C$. marmoratum 0.1960.259, Caladium humboldtii Schott 0.242-0.304, C. picturatum 0.238-0.398, and C. bicolor 0.240-0.301. But cultivars' similarity to one $C$. bicolor accession (Bi2B) and one C. schomburgkii accession (Shm) was high, with Jaccard coefficients being $0.531-0.626$ and $0.658-0.771$, respectively. These two accessions were close to cultivars in the dendrogram (Fig. 2) and in the PCoA plot (Fig. 3). This close similarity may indicate that the selections of $C$. bicolor and C. schomburgkii used in the early crosses to develop caladium cultivars were very similar to these accessions in this study.

Two other C. bicolor accessions (Bi3A and Bi3B) were very similar to each other, with a Jaccard similarity coefficient of 0.900 , but quite dissimilar to $\mathrm{Bi} 7 \mathrm{~B}$, with a similarity coefficient of 0.248-0.261 (Table 5). Compared with Bi7B, Bi3A and Bi3B had similar coefficients with $C$. humboldtii $(0.343-$ 0.386), C. lindenii (0.087-0.093), C. marmoratum (0.275$0.282), C$. picturatum (0.371-0.383), C. steudnirifolium (0.162-0.190), but had much smaller coefficients with $C$. schomburgkii (0.254-0.266) and cultivars (0.240-0.301). Bi3A and Bi3B did not cluster directly with cultivars (Fig. 2).

The similarity coefficients of the $C$. marmoratum accession with C. bicolor, C. humboldtii, C. schomburgkii, C. steudnirifolium, and cultivars were very small $(0.196-0.281)$ and even smaller with $C$. lindenii $(<0.1)$ (Table 5).
Madison (1981) suggested that the species might be a chromosomal race of $C$. bicolor. Loh et al. (1999) showed that this species was vastly different from the AFLP profile of $C$. bicolor, thus not a chromosomal race, but rather a distinct and separate species. Our data support the latter conclusion. The three $C$. humboldtii accessions had low similarity coefficients with other species: 0.230-0.402 with C. bicolor, C. marmoratum, C. picturatum, C. schomburgkii, and cultivars, 0.136-0.204 with C. steudnirifolium, and 0.079-0.089 with $C$. lindenii. Among C. humboldtii accessions, however, the similarity was very high (0.950-0.990), indicating little polymorphism (genetic diversity) within the species. Commercial cultivar White Christmas shares a similar coloration pattern with $C$. humboldtii that is rarely found in other species. Pedigree information was not found for 'White Christmas'. We suspected that $C$. humboldtii might be part of the parentage of 'White Christmas' and contributed to its coloration pattern, but the available data from this study did not provide any support for this speculation.

Caladium lindenii was transferred recently from the genus Xanthosoma Schott to Caladium based on similarity in pollen shedding (Madison, 1981; Mayo and Bogner, 1988). The pollen of Xanthosoma is shed in tetrads, while pollen of Caladium is shed as single grains. Morphologically, $C$. lindenii is very different from other caladium species. The two $C$. lindenii accessions shared a 0.638 similarity coefficient, and they clustered distantly with other caladium species (Fig. 2). Jaccard 
similarity coefficients of $C$. lindenii with the rest of the caladium species accessions were extremely low, 0.060 0.148 , with an average of 0.118 (Table 5). It would be interesting to test if the unique leaf shape, venation, vein color, plant vigor, etc. in C. lindenii could be transferred to caladium cultivars through interspecific hybridization considering this low level of similarity at the molecular level. This low level of similarity also raises a question of whether $C$. lindenii should be placed in another genus. More phylogenetic analysis is needed to answer this question.

IMPLICATIONS FOR DIVERSITY PRESERVATION AND FUTURE BREEDING. The 45 cultivars included in this study represented a high level of phenotypic diversity in morphological, physiological, or horticultural traits such as leaf shape, color, coloration pattern (Wilfret and Hurner, 1982), tuber yield (Wilfret, 1983), sun tolerance (Bates-Cantwell, 2001), cold tolerance (Deng and Harbaugh, 2006), resistance to pythium root rot (Pythium myriotylum Drechs.) (Deng et al., 2005a, 2005b), resistance to fusarium tuber rot (Goktepe et al., 2006), and resistance to root-knot nematodes [Meloidogyne incognita (Kofoid and White) Chitwood] (Dover et al., 2005; McSorley et al., 2003) (Table 1). However, only $44.4 \%$ of the DNA markers detected in cultivars were polymorphic among cultivars, the average similarity coefficient among cultivars was $>0.8$, and all cultivars were highly concentrated in the PCoA plot (Fig. 3). High levels of similarity and low levels of genetic diversity were observed in another study of caladium cultivars using the AFLP marker system (Loh et al., 1999). Seven caladium cultivars of different morphology had Jaccard similarity coefficients between 0.759 and 0.818 and pairwise genetic diversity estimates between 0.241 and 0.182 (Loh et al., 1999). These data indicate a limited amount of genetic diversity at the molecular level in the caladium cultivars. This is in contrast to findings in several other ornamental aroids. For example, $69 \%$ polymorphism was observed in aglaonema (Chen et al., 2004b), 71\% in dieffenbachia (Chen et al., $2004 \mathrm{c}$ ), and $64 \%$ in 30 philodendron cultivars (Devanand et al., 2004). Jaccard similarity coefficients between cultivars were as low as 0.25 in dieffenbachia (Chen et al., 2004c). This limited genetic diversity in caladium cultivars may indicate a narrow genetic base used in cultivar development, lack of genes incorporated from other caladium species, or loss of genetic diversity over time. The drastic drop of number of cultivars from $>2000$ in the early 20th century (Hayward, 1950) to $\approx 90$ at present (Bell et al., 1998; Deng et al., 2005c; Wilfret and Hurner, 1982) may indicate that loss of genetic diversity must have occurred in caladium cultivars. It is necessary to preserve caladium germplasm resources to slow this loss for future genetic improvement of cultivars. To lower costs and reduce the labor associated with germplasm preservation, choices of cultivars may have to be made. The following criteria may serve as a guideline for selecting caladium cultivars for this purpose: (1) those carrying representative or unique DNA fragments or (2) those with desirable ornamental plant characteristics, high commercial (tuber production) values, or stress tolerance and pest resistances. Using these criteria, 27 cultivars were selected out of the 45 cultivars analyzed as candidates to be included in a core collection of caladium cultivars (Table 1). As more molecular marker data or phenotypic evaluation data become available, this list may have to be modified accordingly, but it should be of value to serve as a starting point for making serious and coordinated efforts to preserve caladium germplasm. 
Identifying new traits, especially those visible and of major effects, and incorporating them into new cultivars have been the driving forces in ornamental plant breeding. One major concern in caladium breeding through sexual hybridization has been the scarcity or lack of new color or coloration patterns in breeding populations. Information on the genetic relationships among cultivars revealed through molecular analysis may help identify cultivars as parents for future hybridization breeding. When multiple candidates are available as parents and have similar phenotypes, using those more distantly related or carrying unique markers may result in more diverse progeny populations and improve the chances of finding novel traits or trait combinations. In addition, caladium species accessions are available in a number of botanical gardens. These accessions often do not have impressive leaf colors and coloration patterns, but may possess many unique genes. As shown above, more than $37 \%$ of the DNA fragments were present only in caladium species accessions, but absent in cultivars. This gene pool may be of great significance as efforts are being made to identify host plant resistance to major fungal diseases or root-knot nematodes and to develop disease-resistant cultivars. It is known from studies of other plants that wild and noncultivated germplasm resources often host numerous disease-resistance genes (Eigenbrode, 1996; Innes, 1992).

\section{Literature Cited}

Ahmad, R., M. Okada, J.L. Firestone, C.R. Mallek, and M. Jasieniuk. 2006. Isolation, characterization, and evaluation of microsatellite loci for cultivar identification in the ornamental pampas grass Cortaderia selloana. J. Amer. Soc. Hort. Sci. 131:499-505.

Alwala, S., C.A. Kimbeng, K.A. Gravois, and K.P. Bischoff. 2006 a. TRAP, a new tool for sugarcane breeding: comparison with AFLP and coefficient of parentage. J. Amer. Soc. Sugarcane Technol. 26:62-86.

Alwala, S., A. Suman, J.A. Arro, J.C. Veremis, and C.A. Kimbeng. 2006b. Target region amplification polymorphism (TRAP) for assessing genetic diversity in sugarcane germplasm collections. Crop Sci. 46:448-455.

Bates-Cantwell, T. 2001. The ins and outs of caladiums. Greenhouse Production News 11:12-20.

Bell, M.L., G.J. Wilfret, and D.A. DeVoll. 1998. Survey of caladium tuber producers for acreage of cultivars grown. Proc. Fla. State Hort. Soc. 111:32-34.

Bohn, M., M.F. Utz, and A.E. Melchinger. 1999. Genetic similarities among wheat cultivars determined on the basis of RFLPs, AFLPs and SSRs and their use for predicting progeny variance. Crop Sci. 39:228-237.

Carr, J., M. Xu, J.W. Dudley, and S.S. Korban. 2003. AFLP analysis of the genetic variability in new guinea impatiens. Theor. Appl. Genet. 106:1509-1516.

Chen, J., P.S. Devanand, D.J. Norman, R.J. Henny, and C.T. Chao. 2004a. Interspecific relationships of Alocasia revealed by AFLP markers. J. Hort. Sci. Biotechnol. 79:582-586.

Chen, J., P.S. Devanand, D.J. Norman, R.J. Henny, and C.T. Chao. 2004b. Genetic relationships of Aglaonema species and cultivars inferred from AFLP markers. Ann. Bot. (Lond.) 93:157-166.

Chen, J., P.S. Devanand, N.J. Norman, R.J. Henny, and C.T. Chao. 2004c. Analysis of genetic relatedness of Dieffenbachia cultivars using AFLP markers. J. Amer. Soc. Hort. Sci. 129:81-87.

Chen, J., R.J. Henny, P.S. Devanand, and C.T. Chao. 2006. AFLP analysis of nephthytis (Syngonium podophyllum Schott) selected from somaclonal variants. Plant Cell Rep. 24:743-749.

Chen, J., J. Hu, B.A. Vick, and C.C. January. 2006. Molecular mapping of a nuclear male-sterility gene in sunflower (Helianthus annuus L.) using TRAP and SSR markers. Theor. Appl. Genet. 113:122-127.

Chu, Y. and S. Yazawa. 2001. The variation and the hereditary stability on leaf character of plantlets regenerated from micropropagation in caladiums. J. Chinese Soc. Hort. Sci. 47:59-67 (in Chinese with abstr. in English).

Compositae Genome Project. (n.d.). CGPDB (Compositae Genome Project Database). 13 Oct. 2006. <http://cgpdb.ucdavis.edu/database/ php_my_admin/php_my_admin.php>.

Deng, Z., B.K. Harbaugh, R.O. Kelly, T. Seijo, and R.J. McGovern. 2005a. Pythium root rot resistance in commercial caladium cultivars. HortScience 40:549-552.

Deng, Z., B.K. Harbaugh, R.O. Kelly, T. Seijo, and R.J. McGovern. $2005 \mathrm{~b}$. Screening for resistance to pythium root rot among twentythree caladium cultivars. HortTechnology 15:631-634.

Deng, Z., B.K. Harbaugh, R.K. Schoellhorn, and R.C. Andrew. 2005c. 2003 Survey of the Florida caladium tuber production industry. University of Florida/IFAS Extension Fact Sheet ENH 1007. 16 July 2006. <http://edis.ifas.ufl.edu/EP258>.

Deng, Z. and B.K. Harbaugh. 2006. Evaluation of caladium cultivars for sensitivity to chilling. HortTechnology 16:172-176.

Devanand, P.S., J. Chen, C.T. Chao, and R.J. Henny. 2004. Assessment of genetic relationships among Philodendron cultivars using AFLP markers. J. Amer. Soc. Hort. Sci. 129:690-697.

Dover, K.D., R. McSorley, and K.-H. Wang. 2005. Resistance and tolerance of caladium cultivars to Meloidogyne incognita. Soil Crop Sci. Soc. Florida 64:98-102.

Eigenbrode, S.D. 1996. Host plant resistance and conservation of genetic diversity. 11 July 2006. <http://ipmworld.umn.edu/chapters/ eigenbr.htm $>$.

Goktepe, F., Z. Deng, B.K. Harbaugh, T. Seijo, and N.A. Peres. 2006. Techniques to evaluate caladium cultivars for host resistance to fusarium tuber rot. HortScience 41:1001-1002.

Graf, A.B. 1970. Exotica. 3rd ed. Roehrs, East Rutherford, N.J.

Han, T.H., M. de Jeu, H. van Eck, and E. Jacobsen. 2000. Genetic diversity of Chilean and Brazilian Alstroemeria species assessed by AFLP analysis. Heredity 84:564-569.

Hayward, W. 1950. Fancy-leaved caladiums. Plant Life 6:131-142.

Henny, R.J. 1977. Breeding, growing, and observing Dieffenbachia species and seedlings. Proc. Fla. State Hort. Soc. 90:94-96.

Hu, J. 2006. Defining the sunflower (Helianthus annuus L.) linkage group ends with the Arabidopsis-type telomere sequence repeatderived markers. Chromosome Res. 14:535-548.

$\mathrm{Hu}$, J. and B.A. Vick. 2003. Target region amplification polymorphism: a novel marker technique for plant genotyping. Plant Mol. Biol. Rep. 21:1-6.

Hu, J., O.E. Ochoa, M.J. Truco, and B.A. Vick. 2005. Application of TRAP technique to lettuce (Lactuca sativa L.) genotyping. Euphytica 144:225-235.

Innes, N.L. 1992. Gene banks and their contribution to the breeding of disease resistant cultivars. Euphytica 63:23-31.

Li, G. and C.F. Quiros. 2001. Sequence-related amplified polymorphism (SRAP), a new marker system based on a simple PCR reaction: its application to mapping and gene tagging in Brassica. Theor. Appl. Genet. 103:455-461.

Liu, Z., J.A. Anderson, J. Hu, T.L. Friesen, J.B. Rasmussen, and J.D. Faris. 2005. A wheat intervarietal genetic linkage map based on microsatellite and target region amplified polymorphism markers and its utility for detecting quantitative trait loci. Theor. Appl. Genet. 111:782-794.

Loh, J.P., R. Kiew, A. Kee, L.H. Gan, and Y.-Y. Gan. 1999. Amplified fragment length polymorphism (AFLP) provides molecular markers for the identification of Caladium bicolor cultivars. Ann. Bot. (Lond.) 84:155-161.

Loh, J.P., R. Kiew, A. Hay, A. Kee, L.H. Gan, and Y.-Y. Gan. 2000. Intergeneric and interspecific relationships in Araceae tribe Caladieae and development of molecular markers using amplified fragment length polymorphism (AFLP). Ann. Bot. (Lond.) 85:371-378. 
Madison, M. 1981. Notes on Caladium (Araceae) and its allies. Selbyana 5:342-377.

Mayo, S.J. and J. Bogner. 1988. A new species of Caladium (Araceae) with notes on genetic delimination in the Colocasioideae-Caladieae. Willdenowia 18:231-242.

McGovern, R.J. 2004. Fighting Fusarium. Greenhouse Grower 22:146-150.

McSorley, R., K.-H. Wang, and J.J. Frederick. 2003. Host suitability of caladium varieties to Meloidogyne incognita. Nematropica 34:97-101.

Meerow, A.W., M. Gideon, D.N. Kuhn, and R.J. Schnell. 2005. Isolation and characterization of 10 microsatellite loci from Iris hexagona (Iridaceace). Mol. Ecol. Notes 5:410-412.

Miklas, P.N., J. Hu, N.J. Grünwald, and K.M. Larsen. 2006. Potential application of TRAP (targeted region amplified polymorphism) markers for mapping and tagging disease resistance traits in common bean. Crop Sci. 46:910-916.

Page, R.D.M. 1996. TreEVIEW: an application to display phylogenetic trees on personal computers. Comput. Appl. Biosci. 12:357-358.

Palumbo, R., W. Hong, J. Hu, C.R. Krause, J.C. Locke, R. Craig, D. Tay, and G. Wang. 2005. TRAP markers help categorize a Pelargonium collection. HortScience 40:1067 (abstr.).

Parks, E.J. and J.W. Moyer. 2004. Evaluation of AFLP in poinsettia: polymorphism selection, analysis, and cultivar identification. J. Amer. Soc. Hort. Sci. 129:863-869.

Pavlicek, A., S. Hrda, and J. Flegr. 1999. FreETreE: freeware program for construction of phylogenetic trees on the basis of distance data and bootstrap/jackknife analysis of the tree robustness. Application in the RAPD analysis of the genus Frenkelia. Folia Biol. (Crakow) 45:97-99.
Polston, J.E., M.R. Evans, and J.H. Tsai. 1991. Evidence for association of a mycoplasma-like organism with grassy tuber of caladium. Proc. Fla. State Hort. Soc. 104:334-336.

Rohlf, F.J. 2005. NTSYSpc, numerical taxonomy system, ver. 2.2. Exeter Publishing, Setauket, N.Y.

Sneath, P.H.A. and R.R. Sokal. 1973. Numerical taxonomy: the principles and practice of numerical classification. Freeman, San Francisco.

Tomkins, J.P., T.C. Wood, L.S. Barnes, A. Westman, and R.A. Wing. 2001. Evaluation of genetic variation in the daylily (Hemerocallis spp.) using AFLP markers. Theor. Appl. Genet. 102:489-496.

Ude, G., M. Pillay, E. Ogundiwin, and A. Tenkouano. 2003. Genetic diversity in an African plantain core collection using AFLP and RAPD markers. Theor. Appl. Genet. 107:248-255.

Vuylsteke, M., R. Mank, B. Brugmans, P. Stam, and M. Kuiper. 2000. Further characterization of AFLP data as a tool in genetic diversity assessments among maize (Zea mays L.) inbred lines. Mol. Breed. 6:265-276.

Wilfret, G.J. 1983. Tuber production of caladium cultivars grown in a sandy soil. Proc. Fla. State Hort. Soc. 96:245-248.

Wilfret, G.J. 1986. Inheritance of leaf shape and color patterns in Caladium (Araceae). HortScience 21:750 (Abstr.).

Wilfret, G.J. 1991. 'Florida Fantasy' - a multicolored caladium for containers. University of Florida, Fla. Agr. Expt. Sta. Circ. S-381. Wilfret, G.J. 1993. Caladium, p. 239-247. In: A. de Hertogh and M. le Nard (eds.). The physiology of flower bulbs. Elsevier, New York.

Wilfret, G.J. and G.T. Hurner, Jr. 1982. A survey of caladium cultivars grown in Florida and their characteristics as potted plants. Proc. Fla. State Hort. Soc. 95:190-194. 